\title{
LIST OF PLATES, MAPS, TABLES AND FIGURES
}

\author{
PLATES
}

Frontispiece The successful trader: a retired Alhaji in Ogbomosho vi

Plate 3.1 The Seriki and Pakoyi: two of the earliest Igbetti migrants to Ghana, at a Muslim festival in 1970

Plate 3.2 Chain migration continues: a group of migrants from the second and third generations, Ogbomosho 1971

Plate 4.1 Igbetti trader, wearing a Ghanaian wax print, with his daughter

Plate 4.2 A woman trader from Ogbomosho and her daughter

Plate 5.1 An ornate 'upstairs' house (centre) built in Ogbomosho by a wealthy trader in Tamale

Plate 6.1 Igbetti drummers at a wedding: prior to 1969, the group did good business playing in both Nigeria and Ghana

Plate 6.2 Alhaji Salami, the most senior Yoruba elder in Tamale by the time of the exodus

\section{MAPS}

Map 1.1 West Africa: Western Nigeria and Northern Ghana 2

Map 2.1 Western Nigeria: principal areas involved in migration to Ghana

$\begin{array}{lll}M a p 2.2 & \text { Ghana } & 15\end{array}$

Map 2.3 Northern Ghana 28

Map 2.4 Central Tamale in $1932 \quad 32$

Map 3.1 Tamale in $1969 \quad 56$

TABLES

Table 2.1 Coefficients of concentration of Yoruba migrants in Ghana, 1948, by enumeration area

Table 2.2 Total population and Yoruba population of Ghana, 1960, by enumeration area

Table 2.3 Comparison of coefficients of concentration of Yoruba migrants in Ghana in 1948 and 1960 by 1948 enumeration area

Table 2.4 Numbers and percentages of returned migrants registered by the Western State Government of Nigeria, 1969-71 
Table 2.5 Numbers and percentages of returned migrants registered by the Western State Government of Nigeria, 1969-71, by town

Table 2.6 Comparison of the number of returned migrants registered by the Western State Government of Nigeria in 1969-70 on their return from Ghana with the 1952 Nigerian Census figures

Table 2.7 Distribution of the Yoruba in the Northern Territories of the Gold Coast, 1931, by district

Table 2.8 Yoruba population of the Northern Territories of the Gold Coast, 1931, by age and sex

Table 3.1 Ethnic composition of the population of Tamale, 1960

Table 3.2 Relationships of people responsible for the migration of Yoruba men to Northern Ghana

Table 4.1 Yoruba population of Tamale in 1969 by town of origin

Table 4.2 Residence by ward of Yoruba men in Tamale, 1969, by town of origin

Table 5.1 Principal sources of starting capital of Yoruba men trading independently in Northern Ghana, 1969, by town of origin

Table 5.2 Size of starting capital of Yoruba men trading independently in Northern Ghana, 1969, by year of starting independent trade 108

Table 5.3 Size of starting capital of Yoruba men trading independently in Northern Ghana, 1969, by town of origin

Table 5.4 Main sources of starting capital of Yoruba women trading in Tamale, 1969, by town of origin

Table 5.5 Size of starting capital of Yoruba women trading in Northern Ghana, 1969, by town of origin

Table 5.6 Occupations of Yoruba women trading in Tamale, 1969, prior to marriage

Table 5.7 Goods dealt in by Yoruba men trading in Northern Ghana, 1969

Table 5.8 Selling places of Yoruba women trading in Tamale, 1969, by town of origin

Table 5.9 Sources of goods of Yoruba men trading in Northern Ghana, 1969 , by town of origin

Table 5.10 Involvement of Yoruba men trading in Northern Ghana in rural markets, by town of origin

Table 5.11 Education and literacy of Yoruba men trading in Northern Ghana, 1969, by town of origin

Table 5.12 Method of recording credit sales by Yoruba women trading independently in Tamale, 1969, by town of origin

Table 5.13 Approximate monthly turnover of Yoruba men trading independently in Northern Ghana, 1969, by town of origin

Table 5.14 Approximate monthly turnover of Yoruba women trading in Northern Ghana, 1969, by town of origin 
Table 5.15 Education of children of Yoruba migrants, 1969, by town of origin

Table 5.16 Number of wives of married Yoruba men living in Northern Ghana, 1969

Table 6.1 Close friends of Yoruba men living in Northern Ghana, 1969 , by place of origin

Table 6.2 Close friends of Yoruba men living in Northern Ghana, 1969 , by religion

Table 6.3 Close friends of Yoruba men living in Northern Ghana, 1969 , by occupation

Table 6.4 Origins of friends of Yoruba men living in Northern Ghana, 1969 , by educational level

Table 6.5 Origins of friends of Yoruba men living in Northern Ghana, 1969 , by age

Table 6.6 Origins of friends of Yoruba men living in Northern Ghana, 1969 , by occupation

Table 6.7 Origins of wives of Yoruba men living in Northern Ghana, 1969 , by town

Table 6.8 Places where extant marriages of Yoruba men living in Northern Ghana, 1969, occurred, by year of marriage

\section{FIGURES}

Figure 3.1 The start of migration to Ghana from Ile Olowo, Igbetti 49

Figure 3.2 The start of migration to Ghana from Ile Isale, Ogbomosho 52

Figure 3.3 Relationships of migrants to Ghana from Ile Olowo, Igbetti 60

Figure 3.4 Relationships of migrants to Ghana from Ile Isale, Ogbomosho

Figure 3.5 Relationships of migrants to Ghana from Ile Isale Alagbẹde, Ogbomosho

Figure 3.6 Relationships of migrants to Ghana from Ile Iyanda, Ogbomosho

Figure 3.7 Relationships of migrants to Ghana from Ile Oke, Ogbomosho

Figure 3.8 The spread of migration between compounds in Igbetti 73

Figure 6.1 Institutional structure of the Yoruba community in Tamale 143 